\title{
THE IMPLEMENTATION OF JAPAN-PHILIPPINES MARITIME DIPLOMACY AS PROACTIVE APPROACH TO RESPOND TO THE ASSERTIVE CHINA IN SOUTH CHINA SEA (2012-2017)
}

\author{
Anak Agung Banyu Perwita \& Ivena Ersandi \\ President University \\ Email: aabanyu.perwita@gmail.com
}

\begin{abstract}
Abstrak
Dewasa ini, Laut Cina Selatan ditandai dengan peningkatan belanja pertahanan dan modernisasi militer oleh negara-negara sekitar yang dipicu oleh sifat agresif Cina di kawasan. Keagresifan Cina di Laut Cina Selatan merupakan bentuk ambisi Cina dalam menguasai kawasan tersebut yang merupakan bagian dari kepentingan nasionalnya. Keagresifan tersebut didukung oleh kehadiran dan proyeksi kekuatan militer Cina yang signifikan di kawasan. Jepang dan Filipina memandang keagresifan Cina di Laut Cina Selatan sebagai ancaman, dan sehingga memiliki kepentingan bersama untuk merespon ancaman tersebut. Diperhadapkan dengan keagresifan Cina, sejak 2012, Jepang dan Filipina telah melakukan diplomasi maritim guna menjaga status quo Laut Cina Selatan dari keagresifan Cina. Implementasi dari diplomasi maritim Jepang-Filipina dalam menyaingi keagresifan Cina di Laut Cina Selatan adalah bentuk 'pendekatan proaktif' Jepang, mengikuti kebijakan "Proactive Contribution to Peace" yang dikumandangkan pemerintahan Perdana Menteri Shinzo Abe. Pendekatan proaktif dalam penelitian ini merupakan bentuk konseptualisasi dari balance of power dan cooperative maritime diplomacy.
\end{abstract}

Kata kunci: Laut Cina Selatan, keagresifan Cina, diplomasi maritim, hubungan bilateral Jepang-Filipina, pendekatan proaktif

\begin{abstract}
Nowadays, the South China Sea has been identified with increasing defense spending and military modernization of the neighboring countries which are driven by China's assertiveness in the region. China's assertive behavior in the South China Sea is an expression of its growing ambition over the region which is part of its core interests. China's assertiveness is buoyed by its significant military presence and power projection in the region. Japan and the Philippines are having converging threat perceptions towards China's assertiveness in the South China Sea as well as sharing common interests to balance the assertive China. Contested with China's assertive behavior, since 2012, Japan and the Philippines have been conducting dynamic maritime diplomacy in order to safeguard the status quo of the sea from the assertive China. The implementation of Japan-Philippines maritime diplomacy in responding to China's assertiveness in South China Sea is a form of "proactive approach" by Japan, following the "Proactive Contribution to Peace" banner resounded under Prime Minister Shinzo Abe administration. The proactive approach in this research features the concept of "balance of power" and "cooperative maritime diplomacy".
\end{abstract}

Keywords: South China Sea, China's assertiveness, maritime diplomacy, JapanPhilippines bilateral relations, proactive approach 


\section{Introduction}

The South China Sea has been a center of attention in international affairs for the dynamics of its geopolitics. Its strategic significance to the world is exposed through the abundant amount of resources and potentials such as fishery stocks, minerals and hydrocarbon, and also its position as a strategic commercial shipping lane (Center for Strategic and International Studies, 2016; Cronin, 2013). However the current dynamics of its security environment is identified with territorial tensions among China, Philippines, Brunei Darussalam, Viet Nam, and Malaysia; as shown in Figure 1 (Bender, 2015).

\section{Figure 1. The South China Sea Power}

\section{Struggle}

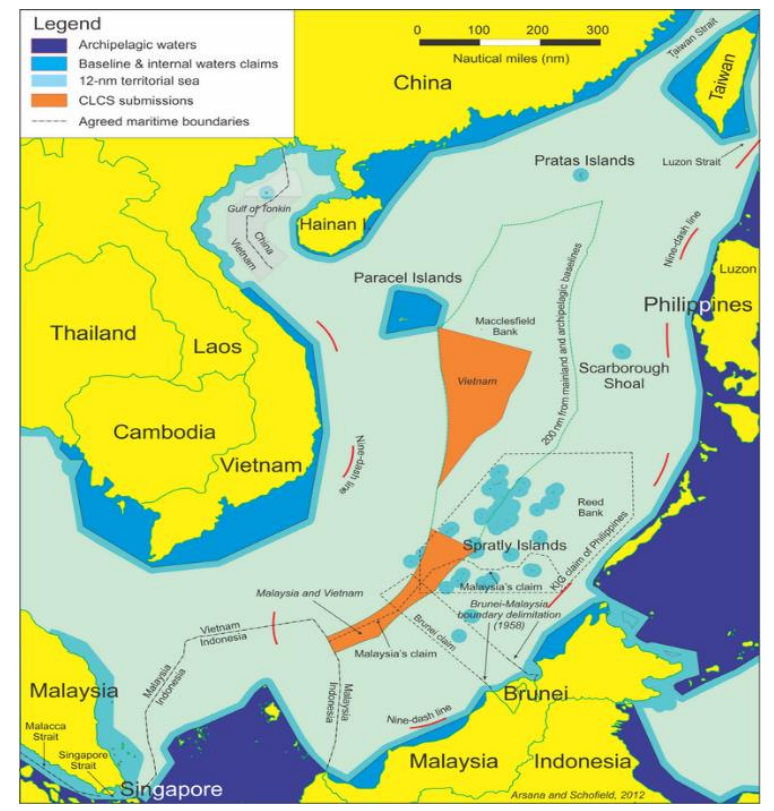

According to analytics firm IHS Markit in 2016, the tensions in the South China Sea would keep escalating and drive an increase of defense spending in the Asia Pacific region for the upcoming five years by nearly 23 percent; rising to $\$ 533$ billion in 2020 from the previously $\$ 435$ billion in 2015 (IHS, 2016). This pour of expense and military modernization are indicating states' responses not merely towards the escalating tensions but also to China's assertive behavior in the region (Dominguez \& Mazumdaru, 2015).

In that regards, the Philippines as one of the claimant states against China in the tension has expressed its concern towards China's assertive behavior in the South China Sea. Meanwhile, Japan has likely shown its response towards the assertive China in the region despite not being a claimant state. On 24 July 2016 in Vientiane, Laos, Japan Prime Minister Shinzo Abe made a statement, "I am seriously concerned with the continuing attempts to change unilaterally the status quo in the East and South China Sea," as his distress towards China's escalating aggressive claims (Al Jazeera, 2016). On the other hand, throughout the past years after coming into power in 2012, Japan under Shinzo Abe has endorsed Japan's vision to be the promoter of the rules and defender of the commons, and also reiterated the banner of "Proactive 
Contribution to Peace" that this article describes as "proactive approach".

Having an increasing convergence of security concerns in the face of China's assertiveness in the South China Sea, Japan and the Philippines have remarkably developed maritime diplomacy in the past few years since 2012 (Cruz de Castro, 2017a). The maritime diplomacy was further characterized with the elevation of Japan-Philippines "strategic partnership" into "strengthened strategic partnership. Hence this article particularly discusses the implementation of Japan-Philippines maritime diplomacy which is the realization of Japan's "Proactive Contribution to Peace" banner in response to the assertive China in the South China Sea.

\section{The Assertive China in South China Sea}

China has been increasingly identified with "assertiveness" since 2009 (Gilsinan, 2015), in what year China submitted its claim statement and ninedashed line map to the United Nations for the first time (Mollman, 2016):

"China has indisputable
sovereignty over the islands in
the South China Sea and the
adjacent waters, and enjoys
sovereign rights and
jurisdiction over the relevant
waters as well as the seabed

"China has indisputable sovereignty over the islands in the South China Sea and the adjacent waters, and enjoys sovereign rights and waters as well as the seabed and subsoil thereof. The above position is consistently held by the Chinese government, and is widely known by the international community."

PRC to UN (Mollman, 2016)

The above claim statement marked a unilateral behavior of China in pursuing its core interest. China has then further asserted its sovereignty claim over the South China Sea by enforcing annual fishing ban, conducting regular maritime patrols, and performing scientific surveys and military exercises in the disputed area (Zhou, 2015).

The whole discourses of the assertive China surfaced as a reaction to China's transition into a more active and aggressive China, that arguably took place in 2009-2010. According to the conceptualization by Richard Q. Turcsányi, Chinese assertiveness is "the behavior in which China actively pursues its interests and acts boldly towards achieving its goals, even if they contradict the interests and/or security of other countries"(Turcsanyi, 2017,13) . The narrative of the assertive China clearly advocates that China does something different than other countries, hence "only those policies of China that are considerably different, qualitatively or quantitatively”, from those other claimants will be regarded as assertive. This 
conceptualization also requires the policies to be different (more assertive) than the proceeding policies, to be regarded as assertive.

Among the narratives of Chinese assertiveness in the South China Sea, here are some of the allegedly assertive actions in the South China Sea as identified based on the conceptualization of "assertiveness" by Richard Q. Turcsányi:

Table 1. Allegedly Assertve Actions of China in South China Sea 2009-2017

\begin{tabular}{|l|c|c|}
\hline \multicolumn{1}{|c|}{ Chinese Action } & $\begin{array}{c}\text { Time of } \\
\text { Occurrence }\end{array}$ & $\begin{array}{c}\text { Category of } \\
\text { Behavior }\end{array}$ \\
\hline 1. Submission of the nine-dash line to the UN & 2009 & No policy change \\
\hline $\begin{array}{l}\text { 2. The more active defense of Chinese fishing } \\
\text { activities, including the imposition of a } \\
\text { fishing ban }\end{array}$ & 2009 - Present & Policy adjustment \\
\hline 3. The cablc-cutting incidcnts & $2011-2012$ & Asscrtivencss \\
\hline 4. The Scarborough Shoal stand-off & 2012 & Assertiveness \\
\hline 5. The Second Thomas Shoal stand-off & Since 2013 & Assertiveness \\
\hline 6. The oil rig incident & 2014 & Assertiveness \\
\hline $\begin{array}{l}\text { 7. Land reclamation, constructions, and } \\
\text { militarization of the outposts }\end{array}$ & 2014 - Present & Asscrtivencss \\
\hline
\end{tabular}

Source: Richard Q. Turcsányi (2017) China's assertiveness in the region is supported and enabled by the steady capacity and infrastructure buildings, especially military facilities on artificial islands that allow China pursuing more control over the South China Sea. The construction of artificial islands and infrastructures such as runways, support buildings, loading piers, and possible satellite communication antennas, has urged other countries to question the aim of the projects (Dingli, et al., 2016). As matter of fact, those intense constructions give China the potential to deploy aircrafts, missiles, and missile defense system to any of its constructed islands, as well as to actualize the possibility of AntiAccess/Area Denial (A2/AD) and Air Defense Identification Zone (ADIZ) that greatly improve China's power projection in the region (Dingli, et al., 2016).

For over a quarter century, China also has broadly reinforced its military forces by maintaining great increases in its defense budget (Ministry of Defense of Japan, 2017b). Though China's detailed military budget allocation can hardly be tracked down due to its lack of transparency, China's military expenditure is discussed to have been invested in whole kinds of weaponry while pursuing a comprehensive military modernization program, which also then contributes to its assertive approach in the South China Sea (Dominguez \& Mazumdaru, 2015).

Meanwhile in 2017, according to The Global Firepower which provides an annual evaluation of the world's military powers, China was positioned on the third rank worldwide in the overall factors; manpower, air power, army strength, navy strength, natural resources (petroleum), logistics, finance, and geographical values (The Global Firepower, 2017). This 
position is indicating that China has significant military presence in the South China Sea that potentially discourages future military activities addressed to China (Ministry of Defense of Japan, 2017a) and benefits China's expansion in the South China Sea.

Table 2. Relevant Military Hardware of Important Actors in South China Sea Region

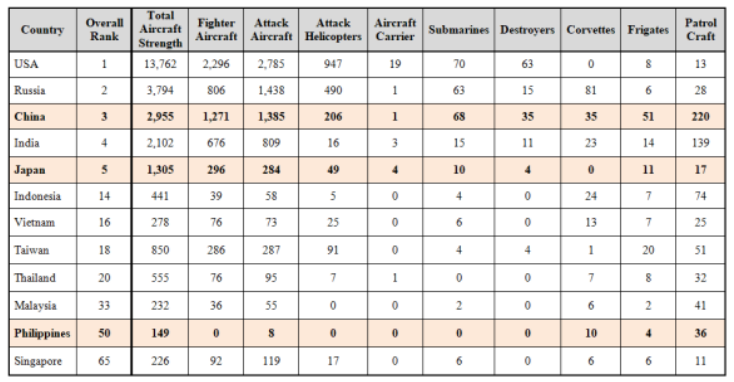

Source: The Global Firepower (2017)

\section{Japan-Philippines Converging Threat}

Perceptions towards Assertive China in South China Sea

China's assertive manner in the South China Sea has subsequently conjured Japan and Philippine's reactions. The Philippines has firmly addressed Chinese behavior in the South China Sea as aggressive and assertive, and also perceived the assertive China in the region as a certain threat for the country:

"The Philippines
considers China's
behavior towards the
Philippines and other
States bordering the South
China Sea to be

aggressive rather than cooperative."

"The Philippines argues that China's assertiveness in its claim to historic rights over all the waters, seabed, and subsoil within the so-called 'nine-dash line' has interfered with the Philippines' enjoyment and exercise of its sovereign rights and jurisdiction under the Convention."

(Permanent Court of Arbitration, 2016)

The assertive China has been projected as threats by both Japan and the Philippines as seen through five dimensions: Structural, Historical, Geopolitical, Socio-Cultural, and Economic as conjured by Robert $\mathrm{O}$. Tilman on threat perceptions concept.

Table 3. Japan-Philippines Converging Threat Perceptions towards China's Assertiveness in South China Sea

PHILIPPINNE JAPAN

\begin{tabular}{|c|l|l|}
\hline STRUCTURAL & Clear, urgent & Clear, urgent \\
\hline HISTORICAL & $\begin{array}{l}\text { Longstanding } \\
\text { dispute in South } \\
\text { China Sea }\end{array}$ & $\begin{array}{l}\text { Longstanding } \\
\text { dispute in East } \\
\text { China Sea }\end{array}$ \\
\hline GEOPOLITICAL & $\begin{array}{l}\text { Close physical proximity; } \\
\text { SCS }\end{array}$ \\
\hline $\begin{array}{c}\text { SOCIO- } \\
\text { CULTURAL }\end{array}$ & Low favorability towards China; \\
& China as greatest threat \\
\hline ECONOMIC & Threatening in & Threatening \\
\hline
\end{tabular}


As displayed in Table 3, in structural dimension, the Philippines government communicated the receipt of threats from the Chinese assertiveness with statement "China's actions constitute a clear and urgent threat to the rights and interests of the Philippines..." that was delivered in the arbitration issued by the Philippines against China on the South China Sea dispute (Permanent Court of Arbitration, 2016). In historical dimension, China and the Philippines have long been involved in the South China Sea dispute over the Spratly Islands and Scarborough Shoal, in which their interactions on the dispute shape the projection of China as a long-term security threat to the Philippines (Sokolsky, Rabasa, \& Neu, 2001). In geopolitical dimension, the physical proximity between China and Philippines' power struggles over the South China Sea is relatively close, especially when considering the position of their military outposts in the disputed areas. In sociocultural dimension, Pew Research Center released "2017 Global Attitude Survey” in which $47 \%$ of Filipinos saw China as a major threat to their country, $30 \%$ saw it as a minor threat, and $8 \%$ took it as no-threat; while $66 \%$ of the Filipinos worry particularly about China's growing military power and deployments in the region (Silver, 2017). The economic dimension is shown by Philippine's statement "China has violated the Convention by: (a) interfering with the exercise of the Philippines' rights under the Convention, including with respect to fishing, oil exploration, navigation, and the construction of artificial islands and installations" (Permanent Court of Arbitration, 2016).

Meanwhile for Japan, in structural dimension, the threat perception started to be seen when the conservative Liberal Democratic Party (LDP) parliaments insisted the 2015 Defense White Paper of Japan to include the aerial photograph of China's extensive island-building in South China Sea, which later included photos of Johnson South Reef and Subi Reef reclamations - showing more alarming Chinese assertiveness in Japan's structural bodies view (Drifte, 2016). In historical dimension, Japan has historically been involved in tensions with China since the First Sino-Japanese War until today's East China Sea dispute; in which China's assertiveness is in tandem with that of in South China Sea (Shoji, 2014), hence Sino-Japanese longstanding dispute in East China Sea contributes to shaping the threat perceptions in the context of South China Sea. In geopolitical dimension, the physical proximity of Japan and China is 
very close, especially when the competing military personnel around the Senkaku/Diaoyu Islands are also added into consideration. In socio-cultural dimension, Japanese favorability view towards China goes as low as $13 \%$ and 90\% of the people regard China's growing military as bad thing (Ministry of Defense of Japan, 2017b; Vice, 2017). In economic dimension, Japan's national economic interests in South China Sea are jeopardized by Chinese assertiveness which involves unilateral fishing ban, foreign oil companies' ban, and extensive sea patrols.

\section{The Implementation of Japan-}

Philippines Maritime Diplomacy (20122017)

Prior to 2012, Japan and the Philippines had not experienced a dynamic security partnership due to Japan's constraints in the pursuant, which was the Article 9 of Japan's 1947 Constitution (Cruz de Castro, 2017a) despite their tight diplomatic and economic relations. In 2011, the Philippines and Japan made a "strategic partnership" which more extensively addressed security issues including maritime affairs and South China Sea dispute, although the maritime cooperation then remained limited (Trajano, 2013). After assuming power in
2012, Japanese Prime Minister Shinzo Abe then instigated the strengthening of both countries" "strategic partnership" through "four initiatives" where the maritime security cooperation was one of the main pillars in the meeting with then President Benigno Aquino (Ministry of Foreign Affairs of Japan, 2013; Trajano, 2013). The initiative was further formally declared and construed in JapanPhilippines "Strengthened Strategic Partnership" in 2015, in which both countries' maritime cooperation has been progressively expanding and taken into priority of their relations. The implementation of Japan-Philippines maritime diplomacy since 2012 has been pursued through:

\section{1) Agreements and Joint}

\section{Statements}

The maritime diplomacy of Japan towards the Philippines is formalized in the "Strengthened Strategic Partnership" which is also strengthened with various agreements that support both countries' commitment in the maritime cooperation. Amongst the agreements are:

"The 2012 Statement of Intent on Defense Cooperation and Exchanges 
between the Department of

National Defense and the

Ministry of Defense"

$>$ "Memorandum on Defense

Cooperation and Exchanges

between the Ministry of

Defense of Japan and the

Department of National

Defense of the Republic of

the Philippines" on 29

January 2015

"Japan-Philippine Joint

Statement" on 26 October

2016

"Japan-Philippines Joint

Statement on Bilateral

Cooperation for the Next

Five Years" on 30 October

2017

\section{2) Contribution and Coordination}

in Regional and International

\section{Arena}

Japan has been actively promoting cooperation with the Philippines that concerns on the regional and international situations and security. This activity is pursued through exchange of information; involvement and exchange in both Peacekeeping Operations Center of the AFP and Japan Peacekeeping Training and Research Center; as well as enhancing cooperation in multilateral framework such as ASEAN Regional Forum (ARF) and ASEAN Defense Ministers' Meeting (ADMM-Plus) (Ministry of Defense of Japan, 2012). Other than the active involvement in the meetings and coordination in regional and international level, the partnership between Japan and the Philippines also highly values rule of law.

\section{3) Political-Security Dialogues,}

\section{Consultations, and Exchanges}

The Philippines and Japan have been actively conducting high-level meetings and consultations to reinforce their security cooperation in the face of China's military assertiveness, in which the two countries discuss and share strategies in handling the challenges posed by China's behavior in the East and South China Seas (Cruz de Castro, 2017a). According to the 2012 Statement of Intent on Defense Cooperation and Exchanges between the DND of the Philippines and the Japan MOD, both countries are committed to conduct defense cooperation and exchanges through: 
Table 4. Political-Security Dialogues \&

Exchanges in Japan-Philippines Maritime

Diplomacy

\begin{tabular}{|c|c|}
\hline \multirow[t]{3}{*}{ High Level Exchanges } & Billateral Defense Ministerial meetings \\
\hline & $\begin{array}{l}\text { Bilateral meetings between Undersecretary of DND of Philippines \& } \\
\text { Vice-Minister of MOD of Japan }\end{array}$ \\
\hline & $\begin{array}{l}\text { Visits between: } \\
\text { - Chief of Staff of AFP \& Chief of Staff of JSDF } \\
\text { - Commanding Generals of Philippine Amy, Nary, Air Force \& } \\
\text { Chief of Staff of Japan Ground, Maritime, Air Self-Defense Forces }\end{array}$ \\
\hline \multirow[t]{2}{*}{ Working Level Exchanges } & $\begin{array}{l}\text { Military-to-military consultations policy tallks on security \& defense } \\
\text { matters at the Director General Deputy Director-General level }\end{array}$ \\
\hline & Staff talks between PN and JMSDFF \\
\hline Unit-to-Unit Exchanges & $\begin{array}{l}\text { Exchange of students between defense educational institutional } \\
\text { Exchange of activities \& exercises, especially between AFP \& JSDF }\end{array}$ \\
\hline $\begin{array}{l}\text { Cooperation in } \\
\text { International Activities }\end{array}$ & $\begin{array}{l}\text { Talks and exchanges between PKO Center of the AFP \& Japan } \\
\text { Peacekeeping Training and Research Center }\end{array}$ \\
\hline \multirow[t]{2}{*}{ Multilateral Cooperation } & $\begin{array}{l}\text { Strengthen cooperation in multilateral frameeroorks such as ARF and } \\
\text { ADMM-Plus }\end{array}$ \\
\hline & $\begin{array}{l}\text { Participate in either Participant's related events, including Meeting of } \\
\text { Senior Defense Officials on Common Security Challenges in the Asia- } \\
\text { Pacific Region and Tolyo Defense Forum }\end{array}$ \\
\hline
\end{tabular}

Source: Ministry of Defense of Japan (2012)

\section{4) Humanitarian}

\section{Assistance/Disaster Relief}

\section{(HA/DR)}

Japan has been constantly contributing to securing peace in Mindanao area in the Philippines, and the HA/DR program is part of the two countries' maritime cooperation focus. In actualizing their HA/DR programs, both countries are focusing on the capacity building that is being buoyed by Japan. The JSDF is coordinating closely with the AFP in assisting the capacity building project, by conducting unit-to-unit exchanges and discussions, joint exercises, and even occasional and mutual ship visits between the PN and JMSDF (Ministry of Defense of Japan, 2012; 2015a).

\section{5) Official Development Assistance (ODA) Loans}

According to ODA Portfolio Review by the Philippines in 2016, Japan through JICA was the biggest source of loans with 45 percent share (USD 5.47 billion) of overall loan portfolio which was amounting to USD 15.60 billion; 66 loans (USD 12.21 billion) and 400 grants (USD 3.39 billion) (National Economic and Development Authority Philippines, 2017a). Among the projects covered by Japan, there are two of them that focus on the capacity building for PCG: (i) Maritime Safety Capability Improvement Project for the Philippine Coast Guard (PCG; (ii) The Project for Enhancement of Coastal Communication System (National Economic and Development Authority Philippines, 2017a). In December 2013, JICA and the Philippines signed an ODA loan agreement that was specifically addressed for "Maritime Safety Capability Improvement Project for the Philippine Coast Guard (PCG)" which was to be conducted through two phases. In the first phase, in 2013, JICA provided an ODA loan up to 18.732 billion yen to the Philippines 
(JICA, 2013). The project that aimed to improve the PCG capabilities was later continued in the second phase in October 2016, in which both JICA and the Philippines signed an ODA loan agreement up to 16.455 billion yen (JICA, 2016).

\section{6) Arms Transfer and Capacity}

\section{Building Assistance}

In July 2013, while Japan was pursuing a strengthened strategic partnership with the Philippines, both countries reached an agreement that Japan would export ten patrol boats to the Philippines through a yen loan as part of ODA provision, aiming to increase the capacity of the PCG (Ministry of Foreign Affairs of Japan, 2013). The later Japan-Philippines "Memorandum on Defence Cooperation and Exchanges" in January 2015 and "Action Plan for Strengthening of the Strategic Partnership" in June 2015 further reiterated both countries' commitments in defense equipment cooperation (Ministry of Defense of Japan, 2015b; Ministry of Foreign Affairs of Japan, 2015). Until today, the development activities of Japan-Philippines cooperation in arms transfer are, among others:
May 2016, agreement on Japan to lease five JMSDF TC-90 surveillance planes to the PN (Cruz de Castro, 2017a).

September 2016, agreement on transferring MSDF TC90 training aircrafts to Philippines; notified that first of ten 40-meter multirole response vessels (MRRVs) had arrived in Philippines with the remaining to steadily follow (Ministry of Foreign Affairs of Japan, 2016b).

26 October 2016, agreement on ODA loans for: (i) two-large scale patrol vessels to Philippines, (ii) steadily maintaining the previous ten-patrol vessels provided (Ministry of Foreign Affairs of Japan, 2016a).

August 2017, Japan MOD reportedly offered its PC-3 patrol aircraft and spare parts for UH-1 helicopters to the Philippines (Kelly \& Kubo, 2017).

12 October 2017, the PCG ordered the first multi-role 
response vessel (MRRV), PCGS Tubbataha, which will be used for patrol, search and rescue, and lawenforcement operation in Philippine's maritime territory (Cruz de Castro, 2016a).

\section{7) Naval Exercises and JMSDF Ships' Port Visits}

In a press conference by Japanese Defense Minister Nakatani in 2015, the minister disclosed the conduct of joint exercise between the JMSDF and PN on 12 May 2015 (Ministry of Defense of Japan, 2015c). The joint naval exercise was part of the realization of security agreement signed by both countries in January 2015, on the implementation of further Code for Unplanned Encounters at Sea (CUES) development and enhancement of their maritime cooperation (Cruz de Castro, 2017a).

Later on 21 June 2015, another joint training was achieved between JMSDF and PN when JMSDF P3-C Orion arrived at the Philippines (Cruz de Castro, 2017a). This activity marked an increasing tempo of JapanPhilippines maritime cooperation and was reportedly focused on enhancing both countries' fleet skills and the interoperability of their navies in HA/DR operations (Cruz de Castro, 2017a). Other than conducting joint naval exercises, JMSDF ships have also made several port visits to the Philippines; 4 visits in 2012, 2 visits in 2013, 7 visits in 2015 (Cruz de Castro, 2017a).

\section{8) Projection of Philippine-Japan Status of Forces Agreement (SOFA)}

Japan and the Philippines have been notably exploring the prospect of SOFA that would enable Japan's forces to access Philippine's military bases, including conducting larger military exercises with the AFP (Cruz de Castro, 2016b). In 2015 during then President Aquino's visit to Japan, the talks about Japan-Philippines VFA were publicly announced and addressed as an importance to boost Japan-Philippines security partnership (Parameswaran, 2017). The presence of a SOFA in Japan-Philippines maritime security is projected to be highly advantageous for the Philippines, because the agreement "would give the Philippines access to training from Japan's highly developed maritime forces, repair 
services for the PN and Coast Guard, and maritime reconnaissance data; all these become more important as the Philippines acquires additional Japanese equipment" (Simon, 2015). Meanwhile Japan would be granted access of refueling and basing facilities in the Philippines, to later perform a joint patrol over lager area of South China Sea (Cruz De Castro, 2015).

\section{Japan-Philippines Maritime Diplomacy}

\section{as Proactive Approach in Responding to}

\section{the Assertive China in South China Sea}

The Philippines, fully aware of its lack on the capability to balance China, recognizes the importance of having internal balancing and to strengthen its relations with other powers that share the same interests:

"It is plain to see that our defense capabilities are no match for any economic giant who will attempt to touch our territories [West Philippine Sea]. There are other ways of tipping the balance of power more favorably towards weaker nations, however.

... the Department will continue to work on the attainment of a credible defense capability for the $A F P$, while at the same time enhance our ties and defense cooperation with nations, who are on the same page with us as far as keeping the peace in the region is concerned. New ties are also being established and nurtured with friendly and peace loving nations." (Department of National Defense Philippines, 2015)

In order to also maintain the status quo of the South China Sea, Japan, on the other hand, offers relevant assistance to the Southeast Asian countries, including the Philippines, by supporting their capacity buildings and urging the countries in the region to cooperate and adhere to the UNCLOS principles (Nirmala, 2016). In that regards, Japan's maritime diplomacy with the Philippines is part and parcel of the country's proactive approach in international affairs. The proactive approach is enabled by and based on the "Proactive Contribution to Peace" banner adopted by Japan, with a clear vision to proactively engage in international affairs:

"The key of national security
is to create a stable and
predictable international
environment, and prevent the
emergence of threats. It is
thus necessary for Japan to
realize an international order
and security environment
that are desirable for Japan,
by playing an even more
proactive role in achieving
peace, stability and
prosperity of the
international community as a
"Proactive Contributor to
Peace" based on the
principle of international


cooperation." (National

Security Strategy, 2013)

Japan's engagement with the Philippines under Shinzo Abe has entered another stage of cooperation from economic-social approach to politicalsecurity approach (Nirmala, 2016). In April 2017, Japan's Ministry of Foreign Affairs released "Priority Policy for Development Cooperation FY 2017" in which Japan aims to contribute more proactively to securing peace, stability and prosperity of the international community by promoting strategic and effective development cooperation (Ministry of Foreign Affairs of Japan, 2017). In that regards, Japan has shown its latest priority policy for the development cooperation, from which the writer sees its application in Japan's maritime diplomacy with the Philippines:

\section{Figure 1 - Japan's Priority Policy for}

\section{Development Cooperation Key Area 1}

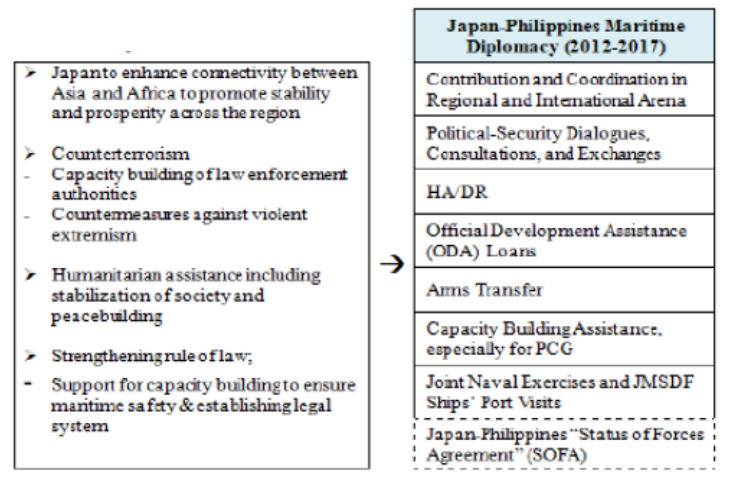

Source: Ministry of Foreign Affairs of Japan (2017)
The above diagram shows that Japan's maritime diplomacy with the Philippine is a practice of Japan's "Proactive Contribution to Peace" as seen through how Japan promotes the notion of "stability, prosperity and rule of law" not only through dialogues. When previously Japan was criticized for its "checkbook diplomacy"; using financial power such as economic aid and investment for increasing diplomatic ties; Japan under Shinzo Abe took a leap towards direct contribution to peace such as; capacity building for PCG, arms transfer, and even joint naval trainings as well as ODA loans addressed to maritime security (Hornung, 2015).

Meanwhile, if seen through Christian Le Mière's maritime diplomacy conceptualization (Figure 3), Japan's strategic partnership with the Philippine leans towards cooperative maritime diplomacy concept. Rather than using coercion as its primary tool, cooperative maritime diplomacy makes use of attraction and values as its tool (Mière, 2014, p. 8), which supports Japan's proactive approach. Referring to Le Mière's conceptualization, JapanPhilippines maritime diplomacy is adopting the following forms of cooperative maritime diplomacy: 
Figure 3. Japan-Philippines Cooperative

\section{Maritime Diplomacy}
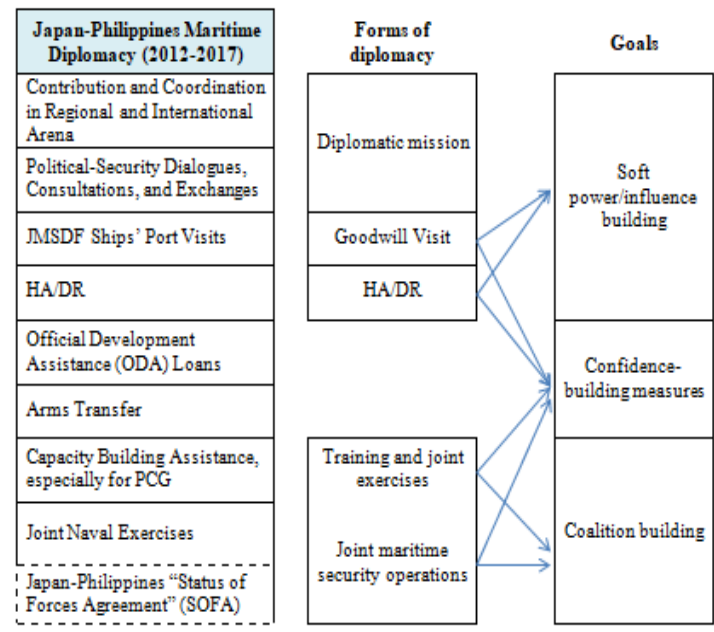

The previous figure shows that Japan-Philippines maritime diplomacy is aiming to enhance diplomatic influence and strengthening the relations with the Philippines through its multilayered exchanges and port visits; enhance the capacity, knowledge, and compatibility with the Philippine's navies through HA/DR and joint trainings; while also build harmonization and confidence among other nations through exercises and joint maritime security operations.

In that regards, cooperative maritime diplomacy has the opportunity to deter any potential rival by showing their confidence and synchronization although it is supposedly not the main aim - which is actually to entice or reassure other governments (Mière, 2014, p. 58). Accordingly, in cooperative maritime diplomacy, the strong power may also support the weak against a possible aggressor; because compelling the other does not have to always take place in coercive maritime diplomacy, though it also does not necessarily mean that the diplomacy needs to be asymmetric (Mière, 2014, p. 58).

\section{Conclusion}

To conclude this article, it can be stated that the assertive China in the South China Sea poses as a security challenge for Japan and Philippines, which further conjure responses from both countries. In that regards, Japan-Philippines maritime diplomacy that started remarkably since 2012 is the joint response towards the assertive China in the region. The implementation of this maritime diplomacy is a form of proactive approach by Japan in the sense that it is in line with the "Proactive Contribution to Peace" banner proclaimed under Shinzo Abe administration. The promotion of democracy, stability, prosperity, and rule of law is clearly pursued in the JapanPhilippines maritime diplomacy, which is also followed with economic aid, capacity building for PCG, and arms transfer; some of which were previously constrained under Japan's pacifist constitution.

In that regards, the article finds that the concept of balance of power is applied 
in the implementation of Japan-Philippines maritime diplomacy, in which the act does not feature formal alliance and direct challenge towards the opposed military preponderance, but rather is pursued through diplomatic efforts, economic efforts and coordination, and increasing military cooperation and technological transfers. Meanwhile, according to Christian Le Mière's maritime diplomacy conceptualization, this maritime diplomacy is applying cooperative maritime diplomacy, which although seems subtle, it has potential to balance China comes from showing confidence and synchronization that could potentially deter the possible aggressor.

\section{About the Authors}

Ivena Ersandi obtained her Bachelor of Arts in International Relations at the School of International Relations, Faculty of Humanities, President University, Indonesia. During her study, she was actively involved in Model United Nations (MUN) and national essay competitions, with several achievements brought home. Currently, she is a research assistant at President Center for International Studies (PRECIS), President University. She has great interest in Diplomacy Studies.
Anak Agung Banyu Perwita is a professor of International Relations at the School of International Relations, President University. He is also a Senior Researcher at President Center for International Studies (PRECIS), $\mathrm{He}$ obtained his MA in International Relations and Strategic Studies from Lancaster University and his Ph.D. from Flinders University, Adelaide. He is also actively involved with the Indonesian Ministry of Defense and the Indonesian National Resilience Council (Dewan Ketahanan Nasional).

\section{Reference}

Al Jazeera. (2016, September 8). Beijing's South China Sea claims scrutinised at summit. Dipetik October 14, 2017, dari Al Jazeera News and Agency: http://www.aljazeera.com/news/20 16/09/south-china-sea-rowovershadows-asean-summit160907051502873.html

Bender, J. (2015, August 10). China wants to build giant floating islands in the South China Sea. Dipetik December 18, 2017, dari Business Insider: http://www.businessinsider.com/ch ina-to-build-giant-floating-islands2015-8/?IR=T

Center for Strategic and International Studies. (2016, March 11). Tensions in the South China Sea explained in 18 maps. Dipetik 
September 30, 2017, dari Business Insider:

http://www.businessinsider.com/te nsions-in-the-south-china-seaexplained-in-18-maps-20151/?IR=T/\#1a-political-map-1

Cronin, P. M. (2013). The Strategic Significance of the South China Sea. Managing Tensions in the South China Sea. Center for Strategic \& International Studies.

Cruz De Castro, R. (2015, June 10). PRESIDENT AQUINO'S VISIT TO TOKYO BOOSTS PHILIPPINEJAPAN PARTNERSHIP IN MARITIME SECURITY. Dipetik January 25, 2018, dari Asia Maritime Transparency Initiative: https://amti.csis.org/presidentaquinos-visit-to-tokyo-boostsphilippine-japan-partnership-inmaritime-security/

Cruz de Castro, R. (2016a). The Duterte Administration's Foreign Policy: Unravelling the Aquino Administration's Balancing Agenda on an Emergent China. Journal of Current Southeast Asian Affairs. Dipetik December 6, 2017, dari nal of Current Southeast Asian Affairs: http://nbnresolving.org/urn/resolver.pl?urn:n bn:de:gbv:18-4-10136

Cruz de Castro, R. (2016b, October 19).

President Duterte Maintains Philippine-Japanese Partnershp as He "Pivots" to China. Dipetik January 25, 2018, dari Asia Maritime Transparency Initiative: https://amti.csis.org/president- duterte-maintains-philippinejapanese-partnership-pivots-china/

Cruz de Castro, R. (2017a, April). 21st Century Japan-Philippines Strategic Partnership: Constraining China's Expansion in the South China Sea. Asian Affairs: An American Review, 44(2), 31-51. doi:10.1080/00927678.2017.12967 43

Department of National Defense Philippines. (2015). Quest for Peace. Philippine Defense Newsletter, 5(1). Dipetik January 25, 2018, dari Department of National Defense Philippines: http://dnd.gov.ph/pdf/PDN/PDN\% 20Volume $\% 205 \% 20$ Issue $\% 201 \% 2$ 02015.pdf

Dingli, S., Economy, E., Haass, R., Kurlantzick, J., Smith, S. A., \& Tay, S. (2016). China's Maritime Dispute. Dipetik January 2, 2018, dari Council on Foreign Relations: https://www.cfr.org/interactives/chi nas-maritime-disputes\#!/

Dominguez, G., \& Mazumdaru, S. (2015, December 18). Are South China Sea tensions triggering an arm race? Dipetik October 4, 2017, dari Deutsche Welle: http://www.dw.com/en/are-southchina-sea-tensions-triggering-anarms-race/a-18927467

Drifte, R. (2016). Japan's Policy towards the South China Sea - Applying "Proactive Peace Diplomacy"? Frankfurt am Main: Peace Research Institute Frankfurt. Dipetik December 2, 2017, dari 
https://www.hsfk.de/fileadmin/HS

FK/hsfk_publikationen/prif140.pdf

Gilsinan, K. (2015, September 25). Cliché of the Moment: 'China's Increasing Assertiveness'. Dipetik October 14, 2017, dari The Atlantic:

https://www.theatlantic.com/intern ational/archive/2015/09/southchina-sea-assertiveness/407203/

Hornung, J. W. (2015, October 27). Gauging Japan's 'Proactive Contributions to Peace'. Dipetik January 25, 2018, dari The Diplomat: https://thediplomat.com/2015/10/ga uging-japans-proactivecontributions-to-peace/

IHS. (2016, June 1). Growing Tensions Around South China Sea to Drive Defence Spending in APAC. Dipetik October 3, 2017, dari IHS Markit: http://news.ihsmarkit.com/pressrelease/aerospace-defensesecurity/growing-tensions-aroundsouth-china-sea-drive-defencespend

JICA. (2013, December 16). Signing of Japanese ODA Loan Agreement with the Republic of the Philippines. Dipetik January 25, 2018, dari JICA: https://www.jica.go.jp/english/new s/press/2013/131216_01.html

JICA. (2016, October 26). Signing of Japanese ODA Loan Agreement with the Republic of the Philippines: Further strengthening the maritime safety capability of the Philippine Coast Guard. Dipetik January 25, 2018, dari JICA:

https://www.jica.go.jp/english/new s/press/2016/161026_01.html

Kelly, T., \& Kubo, N. (2017, August 11). Japan said to offer chopper parts to Philippines as counter to China. Dipetik January 25, 2018, dari Japan Times:

https://www.japantimes.co.jp/news /2017/08/11/national/politicsdiplomacy/japan-said-offerchopper-parts-philippines-counterchina/\#.Wmy4cKiWbIV

Mière, C. L. (2014). Maritime Diplomacy in the 21st Century. New York: Routledge.

Ministry of Defense of Japan. (2012). STATEMENT OF INTENT ON DEFENSE COOPERATION AND EXCHANGES BETWEEN DND OF PHILIPPINES AND MOD OF JAPAN. Dipetik January 25, 2018, dari Ministry of Defense of Japan: http://www.mod.go.jp/j/press/youji n/2012/07/02_st_e.pdf

Ministry of Defense of Japan. (2015a, January 29). Joint Press Release. Dipetik January 25, 2018, dari Ministry of Defense of Japan: http://www.mod.go.jp/j/press/youji n/2015/01/29a_jpr_e.pdf

Ministry of Defense of Japan. (2015b, January 29). MEMORANDUM ON DEFENSE COOPERATION AND EXCHANGES BETWEEN THE MOD OF JAPAN AND THE DND OF THE REPUBLIC OF THE PHILIPPINES. Dipetik January 25, 
2018, dari Ministry of Defense of Japan:

http://www.mod.go.jp/j/press/youji n/2015/01/29a_memo_e.pdf

Ministry of Defense of Japan. (2015c, May 12). Press Conference by the Defense Minister Nakatani (08:4509:02 A.M. May 12, 2015). Dipetik January 25, 2018, dari Ministry of Defense of Japan:

http://www.mod.go.jp/e/press/conf erence/2015/05/12.html

Ministry of Defense of Japan. (2017a). A Strategic analysis of the South China Sea territorial issues. Dipetik December 19, 2017, dari Japanese Ministry of Defense: http://www.mod.go.jp/msdf/navcol /SSG/topics-column/images/t049/049-02.pdf

Ministry of Defense of Japan. (2017b).

Defence White Paper 2017. Dipetik Deecember 6, 2017, dari Ministry of Defense:

http://www.mod.go.jp/e/publ/w_pa per/2017.html

Ministry of Foreign Affairs of Japan.

(2013, July 23). Japan-Philippines

Summit Meeting. Dipetik

November 11, 2017, dari Ministry of Foreign Affairs of Japan: http://www.mofa.go.jp/region/page 6e_000121.html

Ministry of Foreign Affairs of Japan.

(2015, June 4). Japan-Philippines

Joint Declaration: A Strengthened

Strategic Partnership for

Advancing the Shared Principles

and Goals of Peace, Security, and

Growth in the Region and Beyond.
Dipetik January 20, 2018, dari Ministry of Foreign Affairs of Japan:

http://www.mofa.go.jp/s_sa/sea2/p h/page4e_000280.html

Ministry of Foreign Affairs of Japan.

(2016a, October 26). Japan-

Philippines Joint Statement.

Dipetik January 24, 2018, dari

Ministry of Foreign Affairs of Japan:

http://www.mofa.go.jp/files/00019

8399.pdf

Ministry of Foreign Affairs of Japan.

(2016b, September 6). Japan-

Philippines Summit Meeting.

Dipetik January 25, 2018, dari

Minsitry of Foreign Affairs of

Japan:

http://www.mofa.go.jp/s_sa/sea2/p

h/page3e_000568.html

Ministry of Foreign Affairs of Japan.

(2017, April). Priority Policy

Development Cooperation FY2017.

Dipetik January 25, 2018, dari

Ministry of Foreign Affairs of

Japan:

http://www.mofa.go.jp/files/00025

9285.pdf

Mollman, S. (2016, July 7). The line on a 70-year-old map that threatens to set off a war in East Asia. Dipetik October 2, 2017, dari Quartz: https://qz.com/705223/whereexactly-did-chinas-nine-dash-linein-the-south-china-sea-come-from/

National Economic and Development Authority Philippines. (2017a). ODA Portfolio Report Review 2016. Dipetik January 25, 2018, 
dari National Economic and

Development Authority

Philippines:

http://www.neda.gov.ph/wpcontent/uploads/2017/11/ODA-

2016-As-of-August-22-2017.pdf

Nirmala, M. (2016). Japan's New ASEAN

Diplomacy: Strategic Goals, Patterns, and Potential Limitations under the Abe Administration. International Journal of Social Science and Humanity, 6(12), 952957. Dipetik January 25, 2018, dari http://www.ijssh.org/vol6/780HS0067.pdf

Parameswaran, P. (2017, February 16). What's Next for Japan-Philippines Defense Relations Under Duterte? Dipetik January 25, 2018, dari The Diplomat:

https://thediplomat.com/2017/02/w hats-next-for-japan-philippinesdefense-relations-under-duterte/

Permanent Court of Arbitration. (2016, July 12). Award in the South China Sea Arbitration (The Republic of the Philippines v. the People's Republic of China). Dipetik January 15, 2018, dari Permanent Court of Arbitration: https://pcacpa.org/wpcontent/uploads/sites/175/2016/07/ PH-CN-20160712-Award.pdf

Shoji, T. (2014). The South China Sea: A View from Japan. Dipetik November 8, 2017, dari National Institute for Defense Studies Ministry of Defense: http://www.nids.mod.go.jp/english/ publication/kiyo/pdf/2014/bulletin_ e2014_7.pdf

Silver, L. (2017, October 16). How people in Asia-Pacific view China. Dipetik January 17, 2018, dari Pew Research Center: http://www.pewresearch.org/facttank/2017/10/16/how-people-inasia-pacific-view-china/

Simon, S. (2015, September). USSoutheast Asia Relations: Courting Partners. Comparative Connections, 16(2), 53-64. Dipetik January 25, 2018, dari CSIS: https://csisprod.s3.amazonaws.com/s3fspublic/legacy_files/files/publicatio n/1502qus_seasia.pdf

Sokolsky, R., Rabasa, A., \& Neu, C. R. (2001). The Role of Southeast Asia in U.S. Strategy Toward China. Santa Monica: Rand Corporation. Diambil kembali dari https://www.rand.org/pubs/monogr aph_reports/MR1170.html

The Global Firepower. (2017). 2017 Military Strength Ranking. Dipetik January 2, 2018, dari The Global Firepower: https://www.globalfirepower.com/c ountries-listing.asp

Trajano, J. C. (2013, August 5). JapanPhilippines Strategic Partnership: Converging Threat Perception. Dipetik November 11, 2017, dari RSIS Nanyang Technological University: https://www.rsis.edu.sg/rsispublication/rsis/2034-japan- 
philippines-strategicpa/\#.WgcwgmiCzIU

Turcsányi, R. Q. (2017). Chinese Assertiveness in the South China Sea. Cham: Springer International Publishing.

Vice, M. (2017, August 23). In global popularity contest, U.S. and China - not Russia - vie for first. Dipetik February 20, 2018, dari Pew Research Center: http://www.pewresearch.org/facttank/2017/08/23/in-globalpopularity-contest-u-s-and-chinanot-russia-vie-for-first/

Zhou, W. (2015, June). China's growing assertiveness in the South China Sea. Dipetik October 28, 2017, dari Elcano Royal Institute: http://www.realinstitutoelcano.org/ wps/portal/rielcano_en/contenido? WCM_GLOBAL_CONTEXT=/elc ano/elcano_in/zonas_in/asiapacific/ari60-2015-chinas-growingassertiveness-in-the-south-chinasea 